\title{
UPAYA MENINGKATKAN MINAT DAN KEMAMPUAN PEMAHAMAN MATEMATIKA SISWA SMP NEGERI 2 PAMANUKAN MELALUI MODEL PEMBELAJARAN KOOPERATIF TIPE STUDENT TEAM ACHIEVEMENT DIVISIONS (STAD)
}

\author{
Ika Sriyanti, S.Pd,M.Pd \\ Prodi Matematika STKIP SUBANG \\ ikasriyanti99@gmail.com
}

\begin{abstract}
Interest and ability of students' understanding of mathematics can still be said to be less good result in the learning outcomes, especially in SMP Negeri 2 Pamanukan. One effort that can be done by teachers in improving student learning outcomes is to choose a learning model that corresponds to the objectives to be achieved. One of the methods are considered effective and efficient in teaching is STAD cooperative learning methods. The purpose of this study was to determine 1) Describe increase student interest in mathematics who obtain STAD cooperative learning 2) To describe the increased capability of understanding mathematics students who obtain STAD cooperative learning. 3) whether the ability to use mathematical understanding STAD cooperative learning is better than using the ability of understanding mathematical expository. 4) What is the interest of the students who use mathematical learning using cooperative learning and expository. The method used in this research is the Mixed Method and PTK (Classroom Action Research). Instruments used in this research is to test the ability of understanding of mathematics and scale of interest. Where research populations in SMP Negeri 2 Pamanukan class VIII with a randomly selected sample is class VIII-D and VIII-E
\end{abstract}

Keywords: Cooperative learning model STAD, Expository learning models, mathematical comprehension abilities, interests of students.

\section{ABSTRAK}

Minat dan kemampuan pemahaman matematika siswa masih bisa dikatakan kurang baik yang berakibat kepada hasil belajar, khususnya di SMP Negeri 2 Pamanukan. Salah satu upaya yang dapat dilakukan oleh guru dalam meningkatkan hasil belajar siswa adalah dengan memilih model pembelajaran yang sesuai dengan tujuan yang ingin dicapai. Salah satu metode pembelajaran 
yang dirasa efektif dan efisien dalam pengajaran adalah metode pembelajaran kooperatif tipe STAD. Tujuan dari penelitian ini adalah untuk mengetahui 1) Mendeskripsikan peningkatan minat siswa dalam pembelajaran matematika yang memperoleh pembelajaran kooperatif tipe STAD 2) Mendiskripsikan Peningkatan kemampuan pemahaman matematika siswa yang memperoleh pembelajaran kooperatif tipe STAD. 3) apakah kemampuan pemahaman matematika yang mengunakan pembelajaran kooperatif tipe STAD lebih baik daripada kemampuan pemahaman matematika yang menggunakan pembelajaran ekspositori. 4) Bagaiman minat siswa yang menggunakan pembelajaran matematika dengan menggunakan pembelajaran kooperatif dan pembelajaran ekspositori. Metode yang digunakan dalam penelitian ini adalah Mixed Method dan PTK (Penelitian Tindakan Kelas). Instrumen yang digunakan dalam penelitian ini adalah tes kemampuan pemahaman matematika dan skala minat. Dimana populasi penelitiannya di SMP Negeri 2 Pamanukan kelas VIII dengan sampelnya yang dipilih secara acak yaitu kelas VIII-D dan VIII-E

Kata Kunci : Model pembelajaran Kooperatif tipe STAD,model pembelajaran Ekspositori, kemampuan pemahaman matematika, minat siswa.

\section{A. PENDAHULUAN}

Minat belajar merupakan salah satu modal awal dalam pembelajaran siswa, baik ketika berada di rumah maupun di sekolah. Untuk mewujudkan cita-citanya siswa harus memiliki minat belajar yang tinggi. Oleh karena itu guru lebih bekerja keras agar siswa memiliki minat belajar yang tinggi. Bertahun-tahun hasil pembelajaran matematika di sekolah selalu dikeluhkan.

Berdasarkan hal ini guru menyadari bahwa matematika sering dipandang sebagai mata pelajaran yang sulit sehingga banyak siswa yang kurang berminat dan dihindari oleh sebagian besar siswa.
Materi matematika merupakan pelajaran yang sulit bagi sebagian besar siswa. Oleh karena itu berbagai cara dan model pembelajaran mengajar diperlukan untuk memperkecil kesulitan dalam pembelajaran matematika yang dapat meningkatkan kebermaknaan dan pemahaman terhadap matematika. Para guru matematika perlu merenungi kembali "sebenarnya untuk apa matematika diajarkan kepada siswa ?". Tentu bukan untuk mengetahui semua matematika yang ada atau sebanyak mungkin matematika. Tetapi, matematika diberikan kepada siswa untuk membantu siswa agar tertata 
nalarnya, terbentuk kepribadiannya, serta terampil menggunakan matematika dan penalarannya terutama materi aljabar dalam kehidupan sehari-hari.

Dari hasil observasi terlihat aktivitas belajar siswa bahwa minat belajar siswa masih rendah, hal ini ditunjukan dari permasalahan berikut, yaitu: 1) Apabila guru sedang menjelaskan materi masih banyak siswa yang main-main dengan teman sebangkunya.2) Apabila guru bertanya kepada siswa tentang materi yang baru saja diajarkan, kebanyakan siswa diam saja dan tidak merespon pertanyaan dari guru.3) Sebagian besar siswa tidak berani bertanya kepada guru jika mereka belum memahami materi yang diajarkan. 4) masih ada siswa yang kaget jika guru meminta untuk mengerjakan soal di papan tulis . 5) Kadang masih ada siswa yang tidak mengerjakan tugas rumah karena alasan tidak mengerti. Dengan kurangnya minat belajar akan berakibat pada hasil belajar yang kurang maksimal.

Hasil wawancara dengan guru kelas VII dan siswa kelas VIII SMP
Negeri 2 Pamanukan setiap tahunnya, menunjukkan bahwa sebagian besar siswa menganggap matematika merupakan mata pelajaran yang sulit dipahami sehingga banyak siswa yang tidak menyenangi . Yang terjadi di SMP Negeri 2 Pamanukan khususnya kelas VIII minat untuk belajar matematika masih kurang, sehingga hasil belajarnya juga kurang. Rendahnya hasil belajar matematika terlihat dari rendahnya nilai ulangan harian matematika di SMPN 2 Pamanukan,selama tiga tahun terakhir seperti tampak pada tabel 1.1 Sebagai berikut:

Tabel 1.

Hasil Nilai Ulangan Harian Mata Pelajaran Matematika

SMP Negeri 2 Pamanukan dari 3 Tahun Terakhir

\begin{tabular}{|c|c|c|c|}
\hline $\begin{array}{c}\text { Hasil/Tah } \\
\text { un } \\
\text { Pelajaran }\end{array}$ & $\begin{array}{c}2012 / \\
2013\end{array}$ & $2013 /$ & $2014 / 2$ \\
015 \\
\hline $\begin{array}{c}\text { Nilai rata- } \\
\text { rata }\end{array}$ & 55,00 & 60,00 & 50,00 \\
\hline $\begin{array}{c}\text { Nilai } \\
\text { Tertinggi }\end{array}$ & 80,00 & 85,00 & 75,00 \\
\hline $\begin{array}{c}\text { Nilai } \\
\text { Terendah }\end{array}$ & 35,00 & 40,00 & 30,00 \\
\hline (Sumber : Data ulangan harian \\
\hline
\end{tabular}

SMP Negeri 2 Pamanukan)

Berdasarkan data-data di atas maka diperoleh fakta bahwa 
kemampuan pemahaman matematika siswa SMPN 2 Pamanukan masih kurang memuaskan. Sehingga upaya melalui model pembelajaran untuk meningkatkan

kemampuan pemahaman matematika siswa tersebut belum tercapai.

Hasil obsevasi saat proses pembelajaran memperlihatkan bahwa guru belum sepenuhnya melibatkan siswa dalam proses pembelajaran. Guru kebanyakan mengajar dengan menggunakan metode pembelajaran ekspositori yaitu guru hanya mengajar, menjelaskan, memberi contoh, memberi PR dan ulangan harian. Bahkan jarang sekali guru mengajak diskusi tentang materi yang disampaikan. Menurut Rusefendi (2006:290) pembelajaran ekspositori adalah model pembelajaran yang berupa ceramah mulai dengan menerangkan, mendemontrasikan keterampilannya mengenai pola matematika kemudian siswa bertanya, guru memeriksa atau mengecek apakah siswa sudah mengerti apa belum. Guru harus tepat dalam memilih metode dan strategi pembelajaran. Guru yang kurang menguasai materi tentu akan kesulitan di dalam mengajar. Hal ini dapat mengakibatkan siswa kurang mengerti atau mamahami tentang materi yang disampaikan sehingga siswa menjadi malas untuk belajar dan menganggap materi tersebut sulit.

Oleh karena itu salah satu model pembelajaran yang melibatkan siswa secara aktif adalah pembelajaran kooperatif. Anita Lie mengungkapkan bahwa pembelajaran kooperatif merupakan sistem pembelajaran yang memberi kesempatan kepada peserta didik untuk kerja sama dengan siswa lain dalam tugas yang terstruktur. Salah satunya model pembelajaran kooperatif tipe STAD (Student Team Achievement Divisions). Pembelajaran kooperatif tipe Student Team Achievement Division (STAD) yang dikembangkan oleh Robert Slavin dan teman-temannya di Universitas John Hopkin (dalam Slavin, 1995) merupakan pembelajaran kooperatif yang paling sederhana, dan merupakan pembelajaran kooperatif yang cocok digunakan oleh 
guru yang baru mulai menggunakan pembelajaran kooperatif.

Model pembelajaran kooperatif tipe STAD merupakan tim belajar beranggotakan empat orang yang merupakan campuran menurut tingkat kinerjanya, jenis kelamin dan suku. Guru menyajikan pelajaran kemudian siswa bekerja dalam tim untuk memastikan bahwa seluruh anggota tim telah menguasai pelajaran tersebut. kemudian seluruh siswa melakukan kuis tentang materi itu dengan catatan, saat kuis mereka tidak boleh saling membantu. Model Pembelajaran Koperatif tipe STAD merupakan pendekatan Cooperative Learning yang menekankan pada aktivitas dan interaksi diantara siswa untuk saling memotivasi dan saling membantu dalam menguasai materi pelajaran guna mencapai prestasi yang maksimal. Guru yang menggunakan STAD mengajukan informasi akademik baru kepada siswa setiap minggu mengunakan presentasi Verbal atau teks sehingga dapat memberikan perhatian terhadap siswa. Hubungan yang lebih akrab akan terjadi antara guru dengan siswa maupun antara siswa dengan siswa.

Dalam hal ini model pembelajaran kooperatif tipe STAD dalam pelaksanaannya mengacu kepada belajar kelompok siswa. Untuk memenuhi kebutuhan tersebut dan memungkinkan siswa belajar lebih aktif, mempunyai rasa tanggung jawab yang besar, berkembangnya daya kreatif, serta dapat memenuhi kebutuhan siswa secara optimal.

. Pada dasarnya minat adalah penerimaan akan suatu hubungan antara diri sendiri dengan sesuatu diluar sendiri (Slameto, 2003: 180). Semakin kuat atau dekat hubungan tersebut, semakin besar minat untuk belajar matematika. Disini peran guru sangat berpengaruh, seorang guru harus bisa membangkitkan minat belajar siswa untuk belajar matematika dengan metode yang digunakan bahkan materi pelajaran yang lebih mudah dipelajari. Dengan siswa memiliki minat untuk belajar matematika yang tinggi dapat meningkatkan ketekunan belajar siswa bahkan meningkatkan hasil belajar siswa. Dengan minat yang tinggi maka siswa pun akan berusaha 
mempelajari dan memahami materi dengan tujuan untuk mendapatkan hasil ulangan yang meningkat.

Hasil belajar yang baik apabila siswa bisa memahami materi matematika, dengan memahami materi dengan baik maka hasil belajar pun akan meningkat. pemahaman telah diungkapkan Nana Sudjana, pemahaman adalah hasil belajar, misalnya peserta didik dapat menjelaskan dengan susunan kalimatnya sendiri atas apa yang dibacanya atau didengarnya, memberi contoh lain dari yang telah dicontohkan guru dan menggunakan petunjuk penerapan pada kasus lain. Dalam hal ini, siswa dituntut untuk memahami atau mengerti apa yang diajarkan, mengetahui apa yang sedang dikomunikasikan, dan dapat memanfaatkan isinya tanpa keharusan untuk menghubungkan dengan hal-hal yang lain. Karena kemampuan siswa masih terbatas, tidak harus dituntut untuk dapat mensintesis apa yang dia pelajari.

Pembelajaran kooperatif tipe STAD dapat menarik perhatian siswa sehingga dapat menumbuhkan minat mereka terhadap pembelajaran matematika,sehingga siswa dapat dengan mudah memahami matematika. Berdasarkan pembelajaran kooperatif tipe STAD yang dimiliki siswa memungkinkan tumbuhnya minat menjadikan pembelajaran matematika menjadi menarik sehingga diharapkan dapat meningkatkan pemahaman dan minat belajar siswa akan matematika.

Berdasarkan uraian tersebut maka rumusan masalah dalam penelitian ini adalah 1) Apakah model pembelajaran kooperatif tipe Student Team Achievement Divisions (STAD) dapat meningkatkan minat belajar siswa, 2) Apakah model pembelajaran kooperatif tipe Student Team Achievement Divisions (STAD) dapat meningkatkan Pemahaman matematika siswa, 3)Apakah peningkatan kemampuan pemahaman matematika siswa yang menggunakan model pembelajaran kooperatif tipe STAD lebih baik daripada

pembelajaran ekspositori,4)Bagaimana minat siswa yang menggunakan pembelajaran kooperatif tipe STAD dan pembelajaran ekspositori. Tujuan 
penelitian ini untuk

1)Mendeskripsikan

peningkatan

minat siswa dalam pembelajaran matematika yang memperoleh pembelajaran model kooperatif tipe STAD,2)Mendeskripsikan

peningkatan

kemampuan

pemahaman matematika siswa yang memperoleh pembelajaran kooperatif tipe STAD, 3)Untuk mengetahui apakah kemampuan pemahaman matematika yang memperoleh pembelajaran kooperatif tipe STAD lebih baik daripada pembelajaran ekspositori, 4)Untuk mengetahui bagaimana minat siswa yang menggunakan pembelajaran kooperatif tipe STAD dan pembelajaran ekspositori.

\section{B. METODE PENELITIAN}

Penelitian ini dilaksanakan melalaui Penelitian Tindakan kelas (PTK) dan (Mixed Method) metode campuran kualitatif dan kuantitatif. Penelitian ini dilakukan pada bulan Oktober 2015 sampai dengan bulan Desember 2015. Prosedur penelitian tindakan kelas berupa perncanaan, pelaksanaan,pengamatan dan refleksi.Pelaksanaan tindakan kelas dilaksanakan dalam tiga siklus, masing masing siklus tiga pertemuan. Pada perencanaan tindakan dilakukan analisis kurikulum untuk mengetahui kompetensi dasar dan materi yang diajarkan dalam pelaksanaan penelitian,menyiapkan RPP,media

pembelajaran,menentukan

observer,menyusun LKS,serta menyususn instrumen tes dan membentuk kelompok sesuai dengan aturan STAD. Guru menggunakan metode STAD untuk mengajarkan informasi akademik baru kepada siswa.

Pada siklus 1 menyajikan materi dengan kompetensi dasar 1)memahami relasi dan fungsi 2)menyatakan relasi dan fungsi. Siklus II menyajikan materi membuat rumus fungsi, menentukan nilai fungsi,dan menentukan nilai fungsi dalam kehidupan sehari-hari.Siklus III menyajikan materi menggambar grafik fungsi yang berkaitan dengan pemecahan masalah dalam kehidupan sehari-hari.

Dalam metode STAD terdapat beberapa langkah pertama adalah memperkenalkan materi dalam 
presentasi didalam kelas, baik itu materi yang dibuat sendiri maupun materi yang diadaptasikan dari buku teks atau sumber-sumber terbitan lainnya. Langkah kedua dalam STAD adalah membagi siswa kedalam tim atau kelompok, masing-masing terdiri dari lima anggota. Langkah ketiga tiap tim menggunakan LKS dan kemudian saling membantu untuk menguasai bahan ajar melalui diskusi kelompok antar sesama kelompok. Langkah selanjutnyatiap siswa dan tiap tim diberi skor atas penguasaannya terhadap bahan ajar, dan kepada siswa secara individu.

Pengumpulan data dilakukan dengan menggunakan instrumen penelitian berupa tes pemahaman matematika, lembar observasi guru dan siswa, wawancara. Pengolahan dan analisis dalam penelitian ini berupa data kualitatif dan kuantitatif.

\section{HASIL DAN PEMBAHASAN}

Penelitian tindakan kelas ini dilakukan dengan tiga siklus. Penelitian dilaksanakan pada bulan Oktober 2015 sampai bulan

$\begin{array}{lcc}\text { Desember } & 2015 . & \text { Kegiatan } \\ \text { pembelajaran } & \text { dalam } & \text { penelitian }\end{array}$

tindakan kelas ini meliputi kegiatan awal,inti, dan akhir. Pada kegiatan awal guru menyampaikan tujuan pembelajaran yang akan dicapai sebagai acuan bagi siswa. Dalam kegiatan inti guru menyampaikan tujuan pembelajaran yang akan dicapai sebagai acuan bagi siswa. Dalam kegiatan inti guru melaksanakan pembelajaran dengan menggunakan metode STAD sebagai upaya dalam peningkatan pemahaman matematika siswa. Siswa memperhatikan guru kemudian siswa diskusi secara kelompok dilanjutkan siswa melaksanakan kuis individu, setelah kuis dibahas siswa memperoleh poin kemajuan yang akan disumbangkan untuk kelompoknya.

Selama mengikuti proses pembelajaran guru memberikan penilaian kepada siswa, baik dalam aspek penyelesaian masalah, kerjasama, tanggung jawab. Penilaian proses yang diperoleh siswa dapat dilihat dari tabel 1. Pada kegiatan akhir mengadakan evaluasi tentang aktivitas siswa dan guru pada Siklus 1 untuk mengetahui minat siswa selama proses pembelajaran yang menggunakan pembelajaran STAD. 
Tabel 1

Aktivitas Guru dan Siswa

\begin{tabular}{|c|c|c|c|c|}
\hline \multirow{2}{*}{$\begin{array}{c}\text { Observa } \\
\text { si }\end{array}$} & \multicolumn{3}{|c|}{ Siklus 1 } & \multirow{2}{*}{$\begin{array}{c}\text { Klasifika } \\
\text { si }\end{array}$} \\
\cline { 2 - 4 } & 1 & 2 & 3 & \\
\hline Aktivitas & 41 & 41 & 51 & Kurang \\
Guru & $\%$ & $\%$ & $\%$ & \\
\hline Aktivitas & 40 & 40 & 42 & Kurang \\
Siswa & $\%$ & $\%$ & $\%$ & \\
\hline
\end{tabular}

Berdasarkan hasil belajar

matematika pada siklus 1, nampak bahwa hasil belajar pada Siklus 1, jika dilihat dari hasil tes menunjukan siswa belum memahami materi pembelajaran, hal ini terbukti dari hasil rata-rata nilai siklus 1 baru mencapai 60,27 dan standar deviasi 14,64 dan Peningkatannya 0,15. Hal ini menunjukan Peningkatan siklus 1 masih Rendah.

Tabel 2

Ketuntasan dan Peningkatan Siklus 1

\begin{tabular}{|c|c|c|c|c|}
\hline & $\begin{array}{l}\text { Nilai } \\
\text { Dat } \\
\text { a } \\
\text { Awa } \\
\text { I }\end{array}$ & $\begin{array}{l}\text { Nilai } \\
\text { Sikl } \\
\text { us } 1\end{array}$ & $\begin{array}{l}\text { Peni } \\
\text { ngk } \\
\text { atan }\end{array}$ & $\begin{array}{l}\text { Kri } \\
\text { teri } \\
\text { a }\end{array}$ \\
\hline $\begin{array}{l}\text { Rata- } \\
\text { Rata }\end{array}$ & $\begin{array}{l}50,0 \\
0\end{array}$ & $\begin{array}{l}60,2 \\
7\end{array}$ & \multirow{4}{*}{0,15} & \multirow{4}{*}{$\begin{array}{l}\text { Re } \\
\text { nd } \\
\text { ah }\end{array}$} \\
\hline $\begin{array}{l}\text { Standar } \\
\text { deviasi }\end{array}$ & $\begin{array}{l}13,0 \\
3\end{array}$ & $\begin{array}{l}14,6 \\
4\end{array}$ & & \\
\hline $\begin{array}{l}\text { Subyek } \\
\text { yang } \\
\text { tuntas }\end{array}$ & 3 & 11 & & \\
\hline $\begin{array}{l}\text { Subyek } \\
\text { yang } \\
\text { tidak } \\
\text { tuntas }\end{array}$ & 27 & 19 & & \\
\hline
\end{tabular}

Berdasarkan tabel 2 memberikan gambaran bahwa ratarata nilai pemahaman matematika siklus 1 meningkat dibandingkan dengan rata rata data awal sebelum menggunakan model pembelajaran kooperatif tipe STAD. Demikian juga banyaknya siswa yang tuntas pada siklus 1 lebih banyak dibandingkan dengan data awal.

\section{Tabel 3}

Hasil Aktivitas Guru dan Siswa

\begin{tabular}{|l|c|c|c|c|}
\hline $\begin{array}{l}\text { Obser } \\
\text { vasi }\end{array}$ & \multicolumn{3}{|c|}{ Siklus 2 } & Klasifik \\
\hline & 4 & 5 & 6 & \\
\hline Aktivitas & 55 & 61 & 65 & \\
Guru & $\%$ & $\%$ & $\%$ & Cukup \\
\hline Aktivitas & 50 & 54 & 59 & \\
Siswa & $\%$ & $\%$ & $\%$ & Cukup \\
\hline \multicolumn{4}{|c|}{ Hasil Observasi aktivitas guru } \\
\hline
\end{tabular}

dalam pembelajaran siklus 2 sebagai besar aspek berkatagori cukup baik dengan presentase 60,3\%, karena mulai terbiasa menggunakan model pembelajaran kooperatif tipe STAD.

Begitu pun hasil observasi aktivitas siswa pada siklus 2 menunjukan bahwa siswa mulai aktif dalam mengikuti pembelajaran 
dengan menggunakan model pembelajaran kooperatif tipe STAD. Hal ini di tunjukan dari hasil observasi siswa cukup baik dengan presentase $54,3 \%$.

Tabel 4

Ketuntasan dan Peningkatan Siklus 2

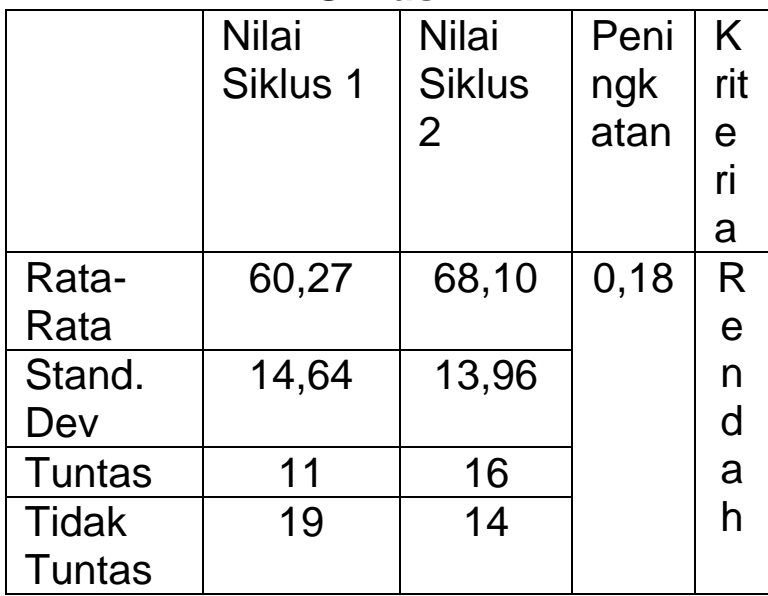

Catatan: Nilai ideal 100 dan KKM 70

Berdasarkan tabel 4 hasil belajar pada siklus 2, jika dilihat dari hasil tes menunjukan siwa masih belum memahami materi pembelajaran walaupun ada peningkatan, hal ini terbukti dari hasil rata-rata nilai Quis 2 baru mencapai 68,10 dengan standar deviasi 13,96 lebih tinggi di bandingkan dengan siklus 1 rata-ratanya 60,27 dengan standar deviasi 14,64, dan peningkatanya 0,18 , yang berkriteria tergolong masih rendah .
Tabel 5

Hasil Observasi Guru dan Siswa

\begin{tabular}{|c|c|c|c|}
\hline Observasi & \multicolumn{2}{|c|}{ Siklus 3 } & Klasifikasi \\
\cline { 2 - 4 } & 7 & 8 & \\
\hline $\begin{array}{c}\text { Observasi } \\
\text { Guru }\end{array}$ & $84 \%$ & $95 \%$ & Baik \\
\cline { 1 - 3 } $\begin{array}{c}\text { Observasi } \\
\text { Siswa }\end{array}$ & $68 \%$ & $68 \%$ & Cukup \\
\hline Hasil observasi aktivitas guru
\end{tabular}

dalam pembelajaran siklus 3 sebagai besar aspek berkatagori baik dengan presentase $89,5 \%$, karena mulai terbiasa menggunakan model pembelajaran kooperatif tipe STAD.

Begitu pun observasi aktivitas siswa pada siklus 3 menunjukan bahwa siswa cukup aktif dalam mengikuti pembelajaran dengan menggunakan model pembelajaran kooperatif tipe STAD. Hal ini di tunjukan dari hasil observasi siswa cukup baik dengan presentase $68 \%$.

Tabel 6

Ketuntasan dan Peningkatan

Siklus 3

\begin{tabular}{|l|l|l|l|l|}
\hline & $\begin{array}{l}\text { Nilai } \\
\text { Sikl } \\
\text { us 2 }\end{array}$ & $\begin{array}{l}\text { Nilai } \\
\text { Sikl } \\
\text { us 3 }\end{array}$ & $\begin{array}{l}\text { Pe } \\
\text { nin } \\
\text { gk } \\
\text { ata } \\
\text { n }\end{array}$ & $\begin{array}{l}\text { Kriteri } \\
\text { a }\end{array}$ \\
\cline { 1 - 3 } $\begin{array}{l}\text { Rata- } \\
\text { Rata }\end{array}$ & $\begin{array}{l}68,1 \\
0\end{array}$ & $\begin{array}{l}80,3 \\
3\end{array}$ & & \\
\cline { 1 - 3 } $\begin{array}{l}\text { Stnd. } \\
\text { Deviasi }\end{array}$ & $\begin{array}{l}13,9 \\
6\end{array}$ & 9,55 & & \\
\cline { 1 - 4 } & 16 & 27 & $\begin{array}{l}0,3 \\
\text { Suby } \\
\text { yang } \\
\text { tuntas }\end{array}$ & $\begin{array}{l}\text { Seda } \\
\text { ng }\end{array}$ \\
\cline { 1 - 2 } & 14 & 3 & & \\
\hline
\end{tabular}

Catatan: Nilai ideal 100 dan KKM 70 
Berdasarkan tabel 6 hasil belajar pada siklus 3, nampak bahwa hasil belajar siklus 3 , jika dilihat dari hasil tes menunjukan siswa memahami materi pembelajaran dengan adanya peningkatan hasil belajar, hal ini terbukti dari hasil ratarata nilai tes siklus 3 mencapai 80,33 dengan standar deviasi 9,55 dan dikatakan tuntas dengan peningkatan 0,34. Dari siklus ke 3 sudah ada peningkatan dibandingkan siklus 1 dan 2.

Berdasarkan tabel 6 memberikan gambaran bahwa ratarata nilai pemahaman matematika siklus 3 lebih tinggi dibandingkan dengan rata rata siklus 2. Demikian juga banyaknya siswa yang tuntas pada siklus 3 lebih banyak dibandingkan dengan siklus 2 .

Tabel 7 Rata-rata Hasil Tes dan Data Awal

\begin{tabular}{|c|c|c|c|c|c|c|}
\hline & $\begin{array}{c}\mathbf{K K} \\
\mathbf{M}\end{array}$ & $\begin{array}{c}\text { Dat } \\
\text { a } \\
\text { Aw } \\
\text { al }\end{array}$ & $\begin{array}{c}\text { Si } \\
\text { klu } \\
\text { S I }\end{array}$ & $\begin{array}{c}\text { Si } \\
\text { klu } \\
\text { s II }\end{array}$ & $\begin{array}{c}\text { Si } \\
\text { klu } \\
\text { s } \\
\text { III }\end{array}$ & $\begin{array}{c}\text { Te } \\
\text { s } \\
\text { Ak } \\
\text { hir }\end{array}$ \\
\hline $\begin{array}{l}\text { Ra } \\
\text { ta- } \\
\text { rat } \\
\text { a }\end{array}$ & 70 & $\begin{array}{c}50,0 \\
0\end{array}$ & $\begin{array}{l}60 \\
20\end{array}$ & $\begin{array}{c}68 \\
10\end{array}$ & $\begin{array}{c}80 \\
30\end{array}$ & $\begin{array}{l}87 \\
50\end{array}$ \\
\hline
\end{tabular}

dapat dideskripsikan skor rata-rata
Data Awal, Tes Siklus I, Siklus II, Siklus III, dan Tes Akhir kemampuan pemahaman matematika pada garfik 1

\section{Grafik 1}

Rata Rata Hasil Tes dan Data Awal

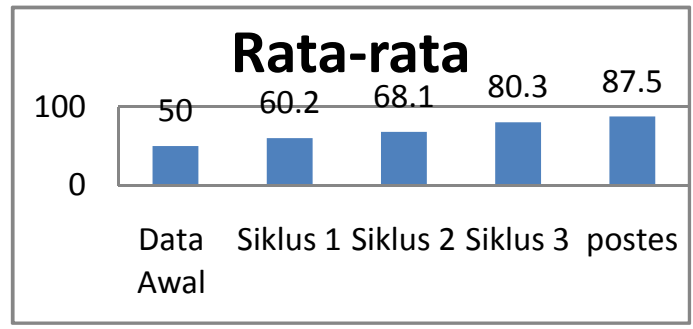

Ket: Data awal adalah rata-rata nilai ulangan harian matematika tahun 2014/2015

Dari grafik 1 Dari tabel 7 menjelaskan bahwa data awal memiliki nilai sebesar 50,00 sedangkan Siklus I mendapatkan rata-rata nilai sebesar 62,20 , Siklus II mendapatkan rata-rata nilai 68,10 , Siklus III mendapatkan rata-rata nilai 80,30, dan tes akhir mendapatkan nilai 87,50. Dilihat dari nilai KKM, yaitu 70 maka pada Data Awal, siklus 1 dan Siklus II belum memenuhi KKM sedangkan pada Siklus III dan Tes Akhir telah memenuhi KKM.

Maka, dapat dilihat dari Data Awal dan Tes Akhir menjelaskan bahwa pembelajaran matematika melalui pendekatan Kooperatif tipe 
STAD dapat meningkatkan kemampuan pemahaman matematika, yaitu meningkatnya Data Awal sebesar 50,00 menjadi 87,50 pada Tes Akhir.

Berdasarkan hasil skor pretes dan postes pada aspek yang diukur. Yaitu aspek kemampuan pemahaman matematika, diperoleh skor minimum, skor maksimum, skor rerata, dan standar deviasi. Perhitungan statistik deskriftif tes kemampuan pemahaman matematika secara lengkap dapat dilihat pada lampiran E, sedangkan secara ringkas disajikan dalam tabel 8

Tabel 8

Rekapitulasi Hasil Pretes dan Postes Kemampuan Matematika

\begin{tabular}{|c|c|c|c|c|c|}
\hline \multirow{2}{*}{$\begin{array}{l}\text { Kelom } \\
\text { pok }\end{array}$} & \multirow{2}{*}{$\begin{array}{l}\text { Sk } \\
\text { or } \\
\text { Ide } \\
\text { al }\end{array}$} & \multicolumn{2}{|c|}{ Pretes } & \multicolumn{2}{|c|}{ Postes } \\
\hline & & $\ddot{x}$ & $\mathrm{Sd}$ & $\ddot{x}$ & Sd \\
\hline $\begin{array}{c}\text { Eksper } \\
\text { imen }\end{array}$ & 20 & $\begin{array}{l}7, \\
53\end{array}$ & $\begin{array}{c}1,7 \\
9\end{array}$ & $\begin{array}{l}17 \\
, 5 \\
0\end{array}$ & 1,79 \\
\hline Kontrol & & $\begin{array}{l}6, \\
20\end{array}$ & $\begin{array}{c}1,9 \\
5\end{array}$ & $\begin{array}{c}14 \\
, 2 \\
0\end{array}$ & 3,49 \\
\hline
\end{tabular}

Tabel 8 menunjukan bahwa rerata hasil pretes kemampuan pemahaman matematika kelas eksperimen dan kelas kontrol hampir sama. Skor rerata pretes kemampuan pemahaman matematika kelas eksperimen adalah 7,53 lebih tinggi dari kelas kontrol dengan standar deviasi 1,79. Skor rerata pretes kemampuan pemahaman matematika kelas kontrol 6,20 dengan standar deviasi 1,95.

Dari hasil perhitungan postes kemampuan pemahaman matematika rerata hasil postes kelas Eksperimen adalah 17,50 lebih tinggi di bandingkan dengan kelas kontrol dengan standar deviasi 1,79. Sedangkan pada kelas kontrol rerata postes kemampuan pemahaman matematika adalah 14,20 dengan standar deviasi 3,49. Sekilas berdasarkan rerata skor postes kelas eksperimen lebih baik dibandingkan dengan kelas kontrol.

Berdasarkan tujuan utama dari penelitian ini adalah untuk membandingkan peningkatan kemampuan pemahaman matematika siswa yang pembelajaran menggunakan model pembelajaran kooperatif tipe STAD dengan siswa yang pembelajarannya menggunakan Ekspositori. Oleh karena itu, perlu 
dihitung mutu peningkatan dengan rumus $\mathrm{N}$-gain. Berikut ini perbandingan N-Gain kedua kelas tersebut:

Tabel 9

Perbandingan $\mathrm{N}$-Gain kemampuan Pemahaman Matematika Kelas Eksperimen dan kelas Kontrol

\begin{tabular}{|c|c|c|c|c|}
\hline Kelompok & \multicolumn{4}{|c|}{ N-Gain } \\
\cline { 2 - 5 } & $\mathrm{X}_{\min }$ & $\mathrm{X}_{\mathrm{ma}}$ & $\ddot{x}$ & $\mathrm{Sd}$ \\
& & $\mathrm{x}$ & & \\
\hline Ekperime & 0,0 & 0,1 & 0,10 & 0,02 \\
$\mathrm{n}$ & 3 & 5 & 7 & 4 \\
\hline Kontrol & 0,0 & 0,1 & 0,08 & 0,03 \\
& 1 & 6 & 5 & 3 \\
\hline
\end{tabular}

Dari hasil perhitungan N-Gain kemampuan

pemahaman

matematika, rerata hasil $\mathrm{N}-$ Gain kelas Eksperimen adalah 0,107 lebih tinggi dibandingkan dengan kelas kontrol, dengan standar deviasi 0,024. Sedangkan pada kelompok kontrol retara $\mathrm{N}$-gain kemampuan pemahaman matematika adalah 0,085 dengan deviasi 0,033 . Sekilas rerata skor N-Gain kelas eksperimen lebih baik dibandingkan dengan kelas kontrol.

Pernyataan ini bisa dibuktikan dari hasil tes pemahaman matematika pada kelas eksperimen yang menggunakan pembelajaran kooperatif tipe STAD. Pada tiap siklus mengalami kenaikan untuk rata-rata ketuntasan materi Relasi dan Fungsi. Ini dapat dilihat dari banyaknya siswa yang memperoleh nilai $d$ atas KKM. Artinya setiap siklus siswa yang tuntas setiap siklusnya semakin bertambah banyak. Hal ini menurut Robert Slavin dan teman-temannya di Universitas John Hopkin (Slavin,1995) dalam pembelajaran kooperatif yang paling sederhana, dan merupakan pembelajaran kooperatif yang cocok digunakan oleh guru yang baru mulai menggunakan pembelajaran kooperatif.

Pembelajaran kooperatif dengan menggunakan model kooperatif tipe STAD memungkinkan siswa untuk bekerjasama dalam kelompoknya. Dan memungkinkan siswa untuk belajar matematika secara bermakna artinya belajar matematika dengan masalah yang ada pada kehidupan sehari-hari.

Dari penjelaskan di atas dapat kita lihat bahwa model pembelajaran kooperatif tipe STAD memiliki keistimewaan tersendiri di banding 
dengan pembelajaran ekspositori. Secara kita tahu bahwa model pembelajaran eskpositori cenderung lebih menoton dan guru memiliki kapasitas yang lebih banyak dalam perannya di banding dalam pembelajaran kooperatif tipe STAD. Selain dari pada itu proses pembelajaran dengan model pembelajaran kooperatif tipe STAD yaitu mengenai fokusnya siswa dalam mengerjkan soal, karena disini pada tahap pengerjaan soal siswa dituntut benar-benar mengerjakan sendiri (individual) semaksimal kemampuan mereka masing-masing, berbeda dengan tahap pengerjaan soal pada pembelajaran ekspositori, dimana guru memberikan kebebasan pengerjaan soal untuk individu ataupun berkelompok,sehingga disini tidak adanya tuntutan pada siswa untuk berpikir sendiri apabila pengerjaaan soalnya berkelompok, kecenderungan siswa mengandalkan kemampuan siswa yang jauh lebih memahami materi yang diajarkan.

Hasil penelitian awal sebelum perlakuan, kemampuan pemahaman matematika siswa baik yang menggunakan pembelajaran kooperatif tipe STAD maupun Ekspositori menunjukan bahwa ada perbedaan kemampuan awal pemahaman matematika antara kelas kontrol dan kelas ekperimen. Hal ini sejalan dengan pendapat Russefendi (2005:53) yang menyatakan bahwa naiknya skor pada postes dibandingkan dengan pretes belum tentu disebabkan karena perlakuan, untuk itu perlu kemampuan awal kedua kelas sehingga peneliti yakin bahwa kemampuan awal kedua kelas sama.

Model pembelajaran kooperatif tipe STAD lebih memberikan kesempatan kepada siswa dibandingkan pembelajaran ekspositori. Pada model pembelajaran kooperatif tipe STAD siswa dituntut untuk melakukan pemahaman konsep sedangkan pada pembelajaran ekspositori hanya menerima materi langsung disajikan oleh guru. Sehingga dapat dilihat dari kemampuan akhir (Postes) siswa yang menggunakan pembelajaran kooperatif tipe STAD memiliki perbedaan antara hasil akhir kemampuan pemahaman matematika yang menggunakan pembelajaran 
kooperatif tipe STAD dengan hasil akhir siswa yang menggunakan pembelajaran ekspositori.

Untuk melihat minat siswa terhadap pembelajaran matematika, siswa diberikan angket minat. Angket tersebut berisikan pernyataan yang berkaitan dengan minat siswa yang menyangkut dengan perasaan siswa, perhatian siswa, konsentrasi siswa, dan kesadaran siswa. Angket diberikan sesudah pembelajaran kooperatif tipe STAD dan juga angket diberikan pada siswa yang menggunakan pembelajaran ekspositori. Pertama Proses pengolahan angket menggunakan MSI untuk mengetahui rata-rata siswa yang menggunakan pembelajaran kooperatif tipe STAD dan pembelajaran ekspositori. Tujuan menggunakan MSI (Method of Successive Interval) untuk merubah data ordinal ke interval.

Tabel 10

\section{Analisis MSI Interval Angket Minat}

\begin{tabular}{|l|c|}
\hline \multicolumn{1}{|c|}{$\begin{array}{c}\text { Model } \\
\text { Pembelajaran }\end{array}$} & Rata-rata \\
\hline $\begin{array}{l}\text { Kooperatif tipe } \\
\text { STAD }\end{array}$ & 91,065 \\
\hline Ekspositori & 85,478 \\
\hline
\end{tabular}

Berdasarkan analisis MSI
bahwa rata-rata siswa yang
mendapatkan
kooperatif tipe STAD rata ratanya
91,065 lebih besar dari rata-rata
siswa yang menggunakan
pembelajaran Ekspositori dengan rata-rata 85,478 .

Sikap seseorang terhadap sesuatu (misalkan terhadap matematika) sangat erat kaitannya dengan minat. Sebagian dari sikap bisa akibat dari minat. Agar siswa berminat atau tetarik terhadap matematika, paling tidak siswa harus melihat kegunaannya, keindahannya, atau karena matematika menantang. Selain itu mungkin juga siswa tertarik kepada matematika karena kesukaannya, argumentasinya jelas, soal-soalnya menantang, gurunya menyenangkan dan sebagainya (Darmin dalam Dahiana,2010: 30).

Menurut Poerwadarminta (Dahiana, 2010: 30) mendefinisikan bahwa sikap adalah pandangan yang berdasarkan pendirian (pendapat atau keyakinan) sangat erat kaitannya dengan minat. Sedangkan minat menurut Russefendi (1991) mengemukakan bahwa minat 
seseorang terhadap matematika merupakan salah satu faktor untuk mengetahui sikap orang tersebut terhadap matematika. Artinya seseorang yang berminat terhadap matematika akan menumbuhkan sikap yang positif terhadap matematika.

Untuk menumbuhkan minat dan sikap positif siswa terhadap matematika perlu diperhatikan antara lain kegunaan matematika bagi siswa dan cara guru menyampaikan matematika kepada siswa. Sehubungan dengan cara penyampaian materi, Hudojo (Dahiana,2013: 31) menjelaskan bahwa keberhasilan siswa belajar matematika dipengaruhi oleh penguasaan pengajar terhadap berbagai cara penyampaian bahasan matematika kepada siswa. Lebih jauh Marinawatie

(Dahiana,2013:13) menegaskan bahwa di dalam kegiatan belajar mengajar guru hendaknya memusatkan perhatian pada usaha membangkitkan minat, semangat, daya cipta (kreativitas) dan kemampuan siswa untuk menemukan dan memecahkan masalah dengan upaya siswa sendiri.
Dilihat dari apa yang terjadi pada penelitian, ternyata minat dilihat dari aktivitas observasi siswa. Banyak faktor yang menyebabkan siswa memberi sikap positif terhadap diberikannya perlakuan dengan mengunakan pembelajaran kooperatif tipe STAD. Seperti terlihat dari skala minat yang peneliti berikan. Dari pernyataan yang peneliti berikan pada siswa, umumnya mereka setuju bahwa pembelajaran kooperatif tipe STAD memberi kemudahan kepada mereka dalam mempelajari matematika, membantu mereka dalam pemahaman matematika serta dapat mengurangi ketidaksenangan siswa terhadap matematika.

Sedangkan angket yang diberikan kepada siswa yang mendapatkan pembelajaran ekspositori, hal ini dimungkinkan karena kondisi siswa benar-benar bersikap negatif, atau karena tidak begitu paham dengan maksud dari pernyataan-pernyataan yang ada pada angket, atau bisa jadi karena siswa beranggapan bahwa pengisisan angket ini tidak perlu jawaban sesungguhnya. 
Indikator minat siswa menurut Slameto (2003) dan Djamarah, Syaiful bahri (2002). Banyak paktor yang menyebabkan siswa bersifat positif terhadap perlakuan dengan pembelajaran kooperatif tipe STAD, seperti terlihat pada hasil skala minat yang peneliti berikan pada siswa yang mendapatkan pembelajaran kooperatif tipe STAD. Dari pernyataan yang peneliti berikan pada siswa, umumnya mereka setuju bahwa pembelajaran kooperatif tipe STAD memberikan kemudahan kepada mereka dalam mempelajari matematika dan dapat mengurangi ketidaksenangan siswa pada matematika.

Dari penjelasan diatas dapat kita simpulkan bahwa minat siswa baik belum tentu memiliki kualitas peningkatan kemampuan pemahamannya baik pula, sebaliknya minat siswa yang kurang baik pun belum tentu memiliki kualitas peningkatan kemampuan pemahaman yang rendah pula. Ini semua terjadi karena minat bukan satu-satunya faktor yang ada mendorong pada kualitas peningkatan kemampuan pemahaman, ada banyak faktor lain yang mempengaruhi pembelajaran terkait.

\section{KESIMPULAN DAN SARAN}

Berdasarkan hasil pengolahan dan analisis data mengenai kemampuan pemahaman matematika dan minat siswa peneliti bisa menyimpulkan hasilnya sebagai berikut:1)Model pembelajaran Kooperatif tipe STAD dapat meningkatkan Minat siswa dalam pembelajaran matematika,2)Model pembelajaran kooperatif tipe STAD dapat meningkatkan kemampuan pemahaman matematika,3)

Peningkatan kemampuan pemahaman matematika yang memperoleh pembelajaran model kooperatif tipe STAD lebih baik dibandingkan dengan siswa yang memperoleh pembelajaran

\section{Ekspositori}

Saran untuk peneliti yang lain 1)Berbagai upaya untuk menjaga kualitas hasil penelitian telah penulis upayakan, tetapi karena waktu, tenagan dan kemampuan maka hal tersebut menyebebkan penulis ini banyak kelemahannya. Penulis 
sarankan agar model pembelajaran kooperatif tipe STAD ini coba diterapkan oleh peneliti lainnya pada materi yang lain atau jengjang pendidikan yang lain, 2)Berdasarkan temuan penelitian yang menunjukan siswa senang dan tertarik terhadap pembelajaran kooperatif tipe STAD ini dapat digunakan dalam proses pembelajaran matematika untuk menciptakan suasana belajar yang menyenangkan dan memudahkan siswa dalam memahami materi yang diberikan.

Saran bagi guru, 1) Hasil dari kesimpulan yang menyatakan bahwa kemampuan pemahaman matematika siswa yang pembelajarannya menggunakan model kooperatif tipe STAD lebih baik dibandingkan dengan pembelajaran ekpositori. Dalam upaya untuk meningkatkan pemahaman matematika siswa, sehingga dengan model pembelajaran kooperatif tipe STAD menjadikan siswa lebih aktif, 2) Guru harus mampu mengunakan model pembelajaran kooperatif tipe STAD karena dapat menjadikan pembelajaran lebih menarik.

\section{DAFTAR PUSTAKA}

Al Rasyid, Harun. (1993) Tehnik Penarikan Sampel dan Penyusunan Skala. Bandung Budiyono, B.U \& Kuswardi Y.(2012) .Model,Media dan Evaluasi Pembelajaran

Matematika.Surakarta:UNS

Budiyono. 2003. Metodolagi penelitian pendidikan. Surakarta: Universitas Sebelas Maret

Firmansyah, E (2013). Peningkatan Kemampuan Pemahaman matematika Melalui Metode Pembelajaran kooperatif tipe STAD (Tesis)

Wahyuni, F (2012). Upaya meningkatkan Minat Belajar Matematika Siswa Kelas VII SMP Negeri 6 Yogyakarta Dengan Menggunakan Media Komik Melalui Model Pembelajaran Kooperatif Tipe Student Teams Achievement Divisions (STAD)" (Jurnal)

Hudojo, (2013). Pengembangan

Kurikulum dan Pembelajaran Matematika. JICA. Universitas Negeri Malang

Hudoyo \& Herman. (1985). Teori

Belajar Dalam Proses BelajarMengajar Matematika. Jakarta. Depdikbud.

Indrawan, R \& Yaniawati, P (2014). Metodologi Penelitian. PT Refika Aditama IrmaPujiati 2008 Peningkatan Motivasidan Ketuntasan Belajar Matematika Melalui 
Pembelajaran Kooperatif Tipe STAD . Jurnal IImiah Kependidikan, Vol. I, No. 1

Kurt,Lewin (1935). A Dynamic Theory of Personality: Selected paper. New york : Mc Graw-Hill

Mega Irhamna. (2009) . Cooperative Learning dengan Model STAD pada Pembelajaran Matematika Kelas VIII SMP Negeri 2 Delitu. Jurnal Penelitian Kependidikan , Tahun 19,Nomor 2, Oktober 2009

Muhibbin Syah. (2005). Psikologi Belajar. Jakarta: Raja Grafindo Persada

Pudjowati, N. (2009) . Implementasi Model STAD ( Student Teams Achievement Divisions)

Sebagai Upaya Peningkatan Apresiasi $H A M$ PadaPesertaDidikKelas VII $S M P$ 1. JurnalLemlit, Volume 3, Nomer 2, Desember 2009

Paul M La Bounty dkk . (2011). International Society of Sports Nutrition position stand: meal frequency.springer.com $\quad(20$ September 2012)

Pembelajaran Kooperatif Tipe STAD (2011)

http://www.sarjanaku.com ( 24 September 2012 )

Purwanita, Y. (2010) Penerapan Model Pembelajaraan Missouri Mathematics Project (MMP) dalam Upaya meningkatkan Penalaran Dan Kemandirian
Siswa SMA. Skripsi FPMIPA UPI: Tidak diterbitkan.

Prof.Dr.H.Wina Sanjaya, Penelitian Tindakan kelas. (Jakarta: Kencana.2009).hal 48

Ratna Widyanti. (2013). Upaya Meningkatkan Minat Dan prestasi Belajar matematika dengan Model Pembelajaran STAD Siswa Kelas V SD negeri 2 Lugobo Tahun pelajaran 2012/2013 (Jurnal)

Ruseffendi, E.T. (2006), Pengantar kepada membantu Guru Mengembangkan

Kompetensinya Dalam pengajaran matematika Untuk Meningkatkan CBSA. Bandung, Tarsito

Rusman (2012) Model-Model pembelajaran. Depok: PT Rajagrafindo

Rusman.(2011). ModelModel Pembelajara Mengembangkan Profesionaisme Guru. Jakarta: Rajawali Pers.

Sardiman. (2004). Interaksi dan Motivasi Belajar-Mengajar. Jakarta: Raja Grafindo Persada.

Sintha \& Sih Dewanti (2010) Usaha Meningkatkan Keaktifan siswa Melalui Metode Pembelajaran melalui Metode Pembelajaran STAD (Student Team Achievent Divisions) di Kelas XI Ipa 1 SMA Negeri 5 Yogyakarta (Jurnal)

Skala Pengukuran dalam Statistika. (2012, February 2). Retrieved 
September 10, 2013, from http://permatawesti.blogspot.co m/2012/02/skala-pengukuran-

dalam-statistika.html

Slameto.(2003). Belajar dan Faktorfaktor yang Mempengaruhinya. Jakarta: Rineka Cipta

Slavin, R.E.(1995)Coopertive learning: teori, riset,and praktik $\left(2^{\text {th }} \quad\right.$ ed). Sydney: AllymandBroon.

Suherman, E . (2003). Evaluasi Pembelajaran Matematika. Bandung : JICA

Turmudi. (2009). Teknik dan Strategi Pembelajaran Matematika Referensi untuk Guru SMP/MTS, Mahasiswa dan
Umum. Jakarta, Leuser Cita Pustaka.

Uyanto,S.S.(2009) Pedoman Analisis data dengan SPSS. Yogyakarta:Graha IImu

Yudha Khrisnawati . (2011). Peningkatan Kualitas Pembelajaran Matematika Dengan Penerapan Model Pembelajaran Kooperatif tipe Student Team Achievement Division (STAD)Di Kelas VIII B SMP Negeri 3 Depok Yogyakarta". (Jurnal)

Wahyudin. (2009). Pembelajaran dan Model-model Pembelajaran. Jakarta : CV. Ipa Abong 